\title{
PHOTOSYNTHETIC RESPONSE TO NITROGEN FERTILIZATION IN SUGARCANE UNDER RAINFED AND HIGH-TEMPERATURE CONDITIONS ${ }^{1}$
}

\author{
SERGIO CASTRO-NAVA*, MARCOS ROLANDO HERRERA-SEPÚLVEDA² ${ }^{2}$ JOSE MANUEL GARCÍA-GIRÓN²
}

\begin{abstract}
Nitrogen is the most important element required for plant growth and development and is the primary nutrient limiting sugarcane production. Field experiments under rainfed condition and some periods with high temperature (above $35{ }^{\circ} \mathrm{C}$ ) were carried out during 2014-2015 at the municipality of Ocampo, Tamaulipas, Mexico. The objective of the study was to determine the effect of varying doses of nitrogen fertilizer on leaf photosynthesis, plant growth, total chlorophyll, and juice quality of sugarcane commercial variety Mex 79-431 in the second ratoon crop. Six nitrogen doses $\left(0,60,90,120,150\right.$, and $\left.180 \mathrm{~kg} \mathrm{~N} \mathrm{ha}^{-1}\right)$ were tested and applied as urea 60 days after harvest, at the beginning of the rainy season. The results of the experiment indicated that the application of nitrogen in ratoon crop had a positive effect on growth and development. It is important to note that further studies are required on the subject, including timing of nitrogen application, application method, soil types, other doses, and other genotypes in the region. The maximum photosynthetic rate $\left(27.68 \mu \mathrm{mol} \mathrm{CO} \mathrm{m}^{-2} \mathrm{~s}^{-1}\right)$ was attained at PAR $1500 \mu \mathrm{mol} \mathrm{m} \mathrm{m}^{-2} \mathrm{~s}^{-1}$ with $90 \mathrm{~kg} \mathrm{~N} \mathrm{ha}^{-1}$. The highest yield was recorded in ratoon crop with a dose of $120 \mathrm{~kg} \mathrm{~N} \mathrm{ha}^{-1}$. At harvest, the juice quality did not show significant variations among the treatments imposed.
\end{abstract}

Keywords: Saccharum officinarum L.. Nitrogen. Fertilizer doses. Photosynthesis. SPAD readings. Rainfed.

\section{RESPOSTA FOTOSSINTÉTICA À FERTILIZAÇÃO COM NITROGÊNIO EM AÇÚCAR EM CONDIÇÕES DE CHUVA E DE ALTA TEMPERATURA}

\begin{abstract}
RESUMO - O nitrogênio é o elemento mais importante necessário para o crescimento e desenvolvimento das plantas e é o nutriente primário que limita a produção de cana-de-açúcar. Experimentos de campo sob condições de sequeiro e alguns períodos com alta temperatura (acima de $35^{\circ} \mathrm{C}$ ) foram realizados durante 20142015 no município de Ocampo, Tamaulipas, Mexico. O objetivo do estudo foi determinar o efeito de doses variadas de fertilizante nitrogenado na fotossíntese foliar, crescimento das plantas, clorofila total e qualidade do suco na variedade comercial de cana-de-açúcar (Mex 79-431) na segunda safra de soca. Foram testadas seis doses de nitrogênio $\left(0,60,90,120,150\right.$ e $\left.180 \mathrm{~kg} \mathrm{~N} \mathrm{ha}^{-1}\right)$. Todo o nitrogênio foi aplicado como uréia 60 dias após a colheita no início da estação chuvosa. Os resultados do experimento indicaram que a aplicação de nitrogênio na cultura da soqueira teve um efeito positivo no crescimento e desenvolvimento. É importante notar que são necessários mais estudos sobre o momento da aplicação de nitrogênio, o método de aplicação, tipos de solo, outras doses e outros genótipos na região. Os níveis máximos de taxa fotossintética $\left(27,68 \mu \mathrm{mol} \mathrm{CO} \mathrm{Cm}^{-2} \mathrm{~s}^{-1}\right)$ foram atingidos a partir de $1500 \mu \mathrm{mol} \mathrm{m} \mathrm{m}^{-2} \mathrm{~s}^{-1} \mathrm{com} 90 \mathrm{~kg} \mathrm{~N} \mathrm{ha}^{-1}$. O maior rendimento foi registrado na cultura da soqueira com uma dose de $120 \mathrm{~kg} \mathrm{~N}^{-1}$. $\mathrm{Na}$ colheita, a qualidade do suco não apresentou variação significativa devido aos tratamentos impostos.
\end{abstract}

Palavras-chave: Saccharum officinarum L.. Nitrogênio. Doses de fertilizantes. Fotossíntese. Leituras SPAD. Cultivo de sequeiro.

\footnotetext{
${ }^{*}$ Corresponding author

${ }^{1}$ Received for publication in $12 / 02 / 2019$; accepted in $07 / 07 / 2020$.

Paper extracted from the bachelor's thesis of the second author.

${ }^{2}$ Faculty of Engineering and Sciences, Universidad Autónoma de Tamaulipas, Victoria, Tamaulipas, México; scastro@docentes.uat.edu.mx - ORCID 0000-0002-8759-001X, marcosherrera8809@gmail.com - ORCID 0000-0002-2736-1442, ggiron@docentes.uat.edu.mx ORCID 0000-0001-8734-4479.
} 


\section{INTRODUCTION}

The important economic and social impact of the Mexican sugar agroindustry is such that it generates more than 500 thousand direct jobs and indirect benefits to more than 2.2 million people (FIRA, 2015). Sugarcane yields in Mexico are low $\left(74 \mathrm{t} \mathrm{ha}^{-1}\right)$, mainly for three reasons: (1) more than $59 \%$ cultivation under rainfed condition (SIAP, 2018); (2) low soil fertility; and (3) high air temperatures (EZENWA et al., 2005; GILBERT et al., 2008; ZHAO; GLAZ; COMSTOCK, 2010).

Sugarcane growth cycle in Mexico is approximately 12 to 14 months. This long cycle, coupled with a high productive potential, requires large quantities of nutrients to sustain annual profitable yields and balance soil nutrient depletion (ZHAO; GLAZ; COMSTOCK, 2014). However, sugarcane producers are actually reducing fertilization for two reasons: (1) environmental protection and (2) decrease in world crop prices (GALLAIS; COQUE; BERTIN, 2008).

Nitrogen is the primary nutrient limiting sugarcane production (WIEDENFELD; ENCISO, 2008; NAGA MADHURI et al., 2011). It is a key component in many biological compounds and plays a major role in photosynthetic activity and crop yield (TAIZ; ZEIGER, 2006). Variation in nitrogen availability due to factors such as variety, crop cycle, agronomic management, soil type, and climate (ISA; HOFMAN; VAN CLEEMPUT, 2006) affects plant development and sugarcane production (ZHAO; GLAZ; COMSTOCK, 2014; SHEKINAH; SUNDARA; RAKKIYAPPAN, 2012; DINH et al., 2019). Numerous studies have documented the need for $\mathrm{N}$ fertilization (NAGA MADHURI et al., 2011; SHEKINAH; SUNDARA; RAKKIYAPPAN, 2012; IZQUIERDO-HERNANDEZ et al., 2016) in sugarcane. In Mexico, very little information is available on how sugarcane responds to $\mathrm{N}$ fertilization at different times of application, from different sources, with different methods, and at different doses. In some sugar mills, the same dose has been used for years without considering these factors (CASTRO; HUERTA, 2015). Preliminary studies indicate that the doses used (120-60-60 and 120-60-70) underestimate (SALGADO-GARCÍA et al., 2005) or overestimate (CASTRO; HUERTA, 2015) the crop demand in some areas. A sugarcane crop with a cane yield of $100 \mathrm{t} \mathrm{ha}^{-1}$ removes $207 \mathrm{~kg}$ $\mathrm{N}$ from the soil (JAGTAP; JADHAVI; KULKARM, 2006). Substantial amounts of $N$ fertilizer are, therefore, necessary for commercial sugarcane production because of the large biomass produced by sugarcane crops (THORBURN; MEIER; PROBERT, 2005). Nevertheless, $\mathrm{N}$ requirements by sugarcane is very low in the plant cane but increase to a maximum of 160 to $180 \mathrm{~kg} \mathrm{~N}^{-1}$ in the second and subsequent ratoons (ROZEFF; WIEDENFELD, 1998).
Since sugarcane requires substantial amounts of water, limited water resources during periods of water stress and high temperatures, especially in rainfed areas, restrict both sugar and cane yields. Moreover, responses to $\mathrm{N}$ fertilizer is low when water availability is reduced thus, further affecting yields (WIEDENFELD, 1995). One of the major problems that hinder efficient sugarcane production is the lack of understanding of the varied responses of sugarcane genotypes to nitrogen (NAGA MADHURI et al., 2011). Variations in varietal response to nitrogen have been widely reported (SRINIVAS et al., 2003; NAGA MADHURI et al., 2011; ZHAO; GLAZ; COMSTOCK, 2014; NAGA MADHURI; HEMANTH; SARALA, 2011; HARI; SRINIVASAN, 2005; IZQUIERDO-HERNÁNDEZ et al., 2016). The common practice is the use of blanket recommendations without considering varietal differences in response to fertilizer doses or differences in physicochemical soil characteristics among different sites and source of $\mathrm{N}$. An alternative to identify efficient genotype related $\mathrm{N}$ use is the analysis of physiological traits (REYNOLDS et al., 2001) but more research on physiological responses of sugarcane to $\mathrm{N}$ rates is required (ZHAO; GLAZ; COMSTOCK, 2014). In Mexico, little attention has been given on the physiological responses of sugarcane varieties to different doses of nitrogen fertilizer. A better understanding on the subject will help select promising cultivars with high yields and high nitrogen use efficiency. Hence, the objective of the study was to determine the effect of varying doses of nitrogen fertilizer on leaf photosynthesis, plant growth, total chlorophyll, juice quality, and yield on a commercial sugarcane variety in the second ratoon crop.

\section{MATERIALS AND METHODS}

A field experiment was carried out from July 31, 2014 to May 30, 2015 in the municipality of Ocampo, Tamaulipas, Mexico $\left(22^{\circ} 51^{\prime} \mathrm{N}, 9^{\circ} 20^{\prime} \mathrm{W}\right.$; altitude $350 \mathrm{~m})$. The second ratoon crop of the commercial sugarcane genotype Mex 79-431 was used to study response to varied fertilizer dose application. Mex 79-431 is a widely cultivated variety in dryland conditions in Mexico. The experiment was conducted under rainfed condition (2212 $\mathrm{mm}$ of accumulated precipitation) and periods with temperatures above $35^{\circ} \mathrm{C}$ (25 days in 12 months). The recommended production practices adopted by the sugar mill in the region were followed for ratoon crop. The crop was harvested at 12 months. The experiment was laid out in a randomized complete block design with four replicates. The plot size in each replication was $5.2 \mathrm{~m} \times 10.0 \mathrm{~m}$ (four rows of $10.0 \mathrm{~m}$ spaced $1.30 \mathrm{~m}$ apart). The treatments consisted of six doses of $\mathrm{N}$ $\left(0,60,90,120,150\right.$, and $\left.180 \mathrm{~kg} \mathrm{~N} \mathrm{ha}^{-1}\right)$, identified as 
DN. Nitrogen was applied as urea 60 days after harvest and at the beginning of the rainy season (in June). Application was done manually to bands in one side of the row. Weed and insect control was effected when required.

All observations were recorded using standard procedures. Six sugarcanes stalks from each plot were randomly selected for estimation of agronomic parameters (plant height, stalk diameter, and internode length), yield, and ${ }^{\circ}$ Brix. Agronomic parameters and ${ }^{\circ}$ Brix were measured before harvest every 30 days. During the maturation phase, in accordance with Bonnett (2014), after 220 days of start of treatment, photosynthesis rate $\left[\mathrm{A}\left(\mu \mathrm{mol} \mathrm{CO} \mathrm{CO}_{2}\right.\right.$ $\left.\mathrm{m}^{-2} \mathrm{~s}^{-1}\right)$ ], stomatal conductance $\left[\mathrm{gs}\left(\mathrm{mol} \mathrm{m} \mathrm{m}^{-2} \mathrm{~s}^{-1}\right)\right]$, transpiration rate $\left[\mathrm{E}\left(\mathrm{mmol} \mathrm{H}_{2} \mathrm{O} \mathrm{m}^{-2} \mathrm{~s}^{-1}\right)\right]$, and leaf temperature $\left[\mathrm{T}_{\text {leaf }}\left({ }^{\circ} \mathrm{C}\right)\right]$ were measured in the middle part of the second expanded young leaf with a LI6400 portable photosynthesis system (Li-COR, Lincoln, Nebraska, USA) equipped with a $2 \times 3 \mathrm{~cm}^{2}$ LED chamber; a flow of $500 \mathrm{~mol} \mathrm{~s}^{-1}$ and a $\mathrm{CO}_{2}$ concentration of $400 \mu \mathrm{mol} \mathrm{mol}{ }^{-1}$ were setup. The photosynthetically active radiation (PAR) response curves were constructed at different hours of the day $(7,10,14,17$, and $19 \mathrm{~h})$, identified as DAT, on a completely sunny day for all $\mathrm{N}$ fertilizer dose application treatments. SPAD (soil plant analysis development) values were also recorded when the agronomic parameters were measured in all active leaves at three different parts (apex, middle, and base of leaf) using a SPAD meter (SPAD-502, Minolta, Japan). Cane yield was recorded at the age of twelve months from the plots and were converted to yield per ha $\left(\mathrm{t} \mathrm{ha}^{-1}\right)$. At the same time, juice samples were drawn from six canes cut at random in each plot to determine juice quality $\left({ }^{\circ}\right.$ Brix) using a refractometer
(Pocket Digital, Thompson Scientific, Swedesboro, NJ, USA). During the experimental period, rainfall $\left(\mathrm{mm}\right.$ month $\left.^{-1}\right)$, maximum temperature $\left(T_{\max }\right)$, and minimum temperature $\left(T_{\min }\right)$ were recorded using a HOBO Weather Station (Onset Computer Corp., Bourne, MA, USA) data logger once every hour.

For the agronomic parameters, SPAD units, yield, and ${ }^{\circ}$ Brix, analysis of variance was conducted for a randomized complete block design. The Tukey's multiple comparison test to determine variation among the six treatments was conducted $(\infty=0.05)$. For the $\mathrm{N}$ doses factor and yield, quadratic polynomial regression test was applied. The statistical software SAS (SAS, 2010) and Sigma Plot ${ }^{\circledR} 13$ (Systat Software Inc., San Jose, CA, USA) were used.

\section{RESULTS AND DISCUSSION}

\section{Environmental Conditions}

Overall, there was significant variability in environmental parameters (Figure 1), such as $\mathrm{T}_{\max }$, $\mathrm{T}_{\min }$, and precipitation during the experiment. In fact, the $\mathrm{T}_{\max }$ fluctuated from 11.0 to $41.5^{\circ} \mathrm{C}$ and the $\mathrm{T}_{\min }$ from 5.4 to $25.5{ }^{\circ} \mathrm{C}$. The $\mathrm{T}_{\max }$ reached $\geq 35{ }^{\circ} \mathrm{C}$ during the 25 days of the months of April and May. This period coincides with the time of low precipitation and high temperature. A total rainfall of $2212 \mathrm{~mm}$ was received during the experiment of which approximately 51\% (i.e., $1119 \mathrm{~mm}$ ) was recorded in the months of June $(551 \mathrm{~mm})$ and September $(568 \mathrm{~mm})$. The highest precipitation recorded was in the month of August $(253 \mathrm{~mm})$.

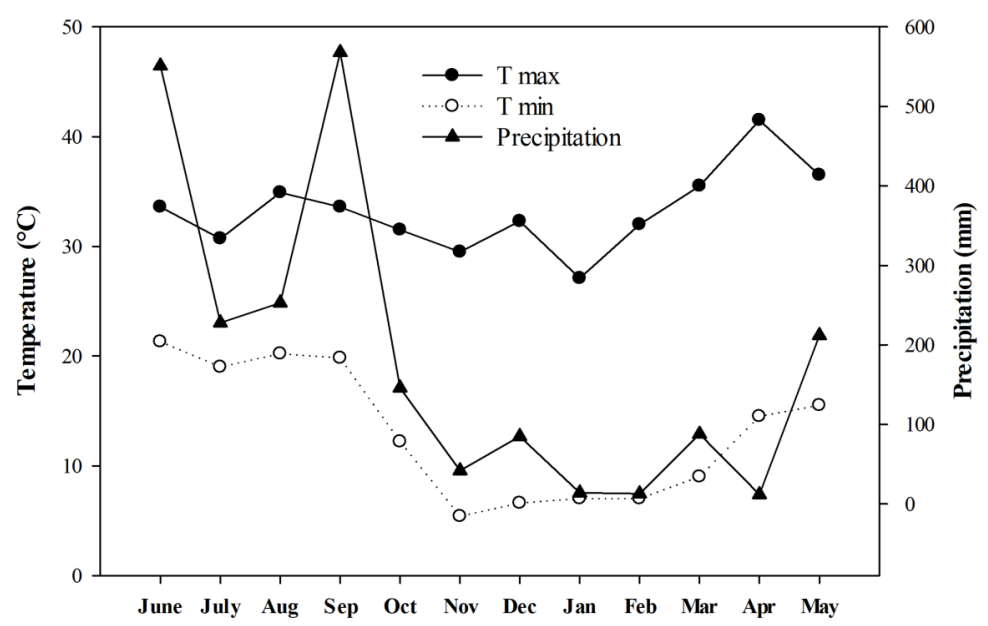

Figure 1. Meteorological data during the experimental period.

\section{Agronomic Parameters}

With respect to nitrogen doses, significant differences were observed in the agronomic parameters, such as plant height, stem diameter, internode length, ${ }^{\circ}$ Brix, and SPAD in the ratoon crop (Table 1); however, the interaction nitrogen doses $\mathrm{x}$ days (DN x DAT) was not significant. Similar results 
were reported by Naga Madhuri et al (2011) and Naga Madhuri, Hemanth and Sarala (2011), who indicated that yield attributing characters were positively influenced by the increased dose of nitrogen. Our results, however, differ from the results reported by (SHEKINAH; SUNDARA; RAKKIYAPPAN, 2012, NAGA MADHURI et al., 2011, NAGA MADHURI; HEMANTH; SARALA, 2011) in relation to plant height, stem diameter, internode length, and ${ }^{\circ}$ Brix with non-significant differences between treatments (Table 2) as influenced by nitrogen levels towards the end of the experiment (261 days after treatment application). This could be due to the early application of nitrogen (eight weeks after harvest), which probably was not sufficient to maintain the observed differences throughout the cycle until the next harvest. Plant height is also a major parameter of growth and yield in sugarcane. Although length, thickness, and shape of internodes are varietal characteristics, the rate of elongation and length of internodes are also influenced by nutrient availability, and hence, plant height provides information about the general conditions of the crop (sunlight, air temperature, and soil water availability). The applied nitrogen has significant (Figure 2) influence on increase in plant height, stem diameter, and internode length of + $12.5 \%,+5.4 \%$, and $+5.4 \%$ respectively. All $\mathrm{N}$ doses had a positive effect on height and produced tall canes. The results are in accordance with (NAGA MADHURI et al., 2011, NAGA MADHURI; HEMANTH; SARALA, 2011) for promising early and middle maturing sugarcane varieties. The response in plant height was caused by a significant response in internode length; the longest internode was observed 100 days after treatment application and for the dose treatment of $180 \mathrm{~kg} \mathrm{~N} \mathrm{ha}^{-1}$ (Figure 2c). For stem diameter, the differences were not as consistent as for plant height; the largest stem diameter was observed with the dose treatment of $150 \mathrm{~kg} \mathrm{~N} \mathrm{ha}^{-1}$.

Table 1. Summary of analysis of variance for agronomic, SPAD, and ${ }^{\circ}$ Brix characteristics in response to soil nitrogen content in ratoon crop.

\begin{tabular}{ccccccr}
\hline Source & d.f. & $\begin{array}{c}\text { Plant height } \\
(\mathrm{m})\end{array}$ & $\begin{array}{c}\text { Stem diameter } \\
(\mathrm{mm})\end{array}$ & $\begin{array}{c}\text { Internode length } \\
(\mathrm{cm})\end{array}$ & $\begin{array}{c}\left({ }^{\circ} \text { Brix }\right) \\
\text { SPAD }\end{array}$ \\
\hline Doses (DN) & 5 & $<0.001$ & $<0.001$ & $<0.001$ & $<0.05$ & $<0.001$ \\
Days (DAT) & 7 & $<0.001$ & $<0.001$ & $<0.001$ & $<0.001$ & $<0.001$ \\
DN x D & 35 & $\mathrm{~ns}$ & $\mathrm{~ns}$ & 6.9 & 3.9 & $\mathrm{~ns}$ \\
CV (\%) & 6.4 & 5.8 & & & & 7.1 \\
\hline
\end{tabular}

d.f.: degrees of freedom; SPAD: soil plant analysis development.

Table 2. Agronomic and ${ }^{\circ}$ Brix characteristics in response to soil nitrogen content in ratoon crop at 261 days after treatment application.

\begin{tabular}{|c|c|c|c|c|c|}
\hline Nitrogen & Plant & Stem & Internode & & \\
\hline Levels & height & diameter & length & ${ }^{\circ}$ Brix & SPAD \\
\hline$\left(\mathrm{kg} \mathrm{N} \mathrm{ha}^{-1}\right)$ & $(\mathrm{m})$ & $(\mathrm{mm})$ & $(\mathrm{cm})$ & & \\
\hline 0 & $1.99 \pm 0.03$ & $27.3 \pm 0.29$ & $10.7 \pm 0.06$ & $24.5 \pm 0.22$ & $35.0 \pm 0.37$ \\
\hline 60 & $2.16 \pm 0.08$ & $28.8 \pm 0.30$ & $10.9 \pm 0.32$ & $24.5 \pm 0.13$ & $33.2 \pm 0.75$ \\
\hline 90 & $2.24 \pm 0.03$ & $26.9 \pm 0.62$ & $11.2 \pm 0.43$ & $24.1 \pm 0.20$ & $34.9 \pm 0.16$ \\
\hline 120 & $2.24 \pm 0.08$ & $27.9 \pm 0.69$ & $11.1 \pm 0.50$ & $24.4 \pm 0.13$ & $32.5 \pm 0.92$ \\
\hline 150 & $2.24 \pm 0.06$ & $28.5 \pm 0.80$ & $11.3 \pm 0.25$ & $24.4 \pm 0.14$ & $32.4 \pm 0.14$ \\
\hline 180 & $2.24 \pm 0.06$ & $27.7 \pm 0.96$ & $11.2 \pm 0.34$ & $24.4 \pm 0.07$ & $34.1 \pm 0.14$ \\
\hline $\begin{array}{c}\text { Tukey } \\
(\infty=0.05)\end{array}$ & ns & ns & ns & ns & 1.839 \\
\hline
\end{tabular}



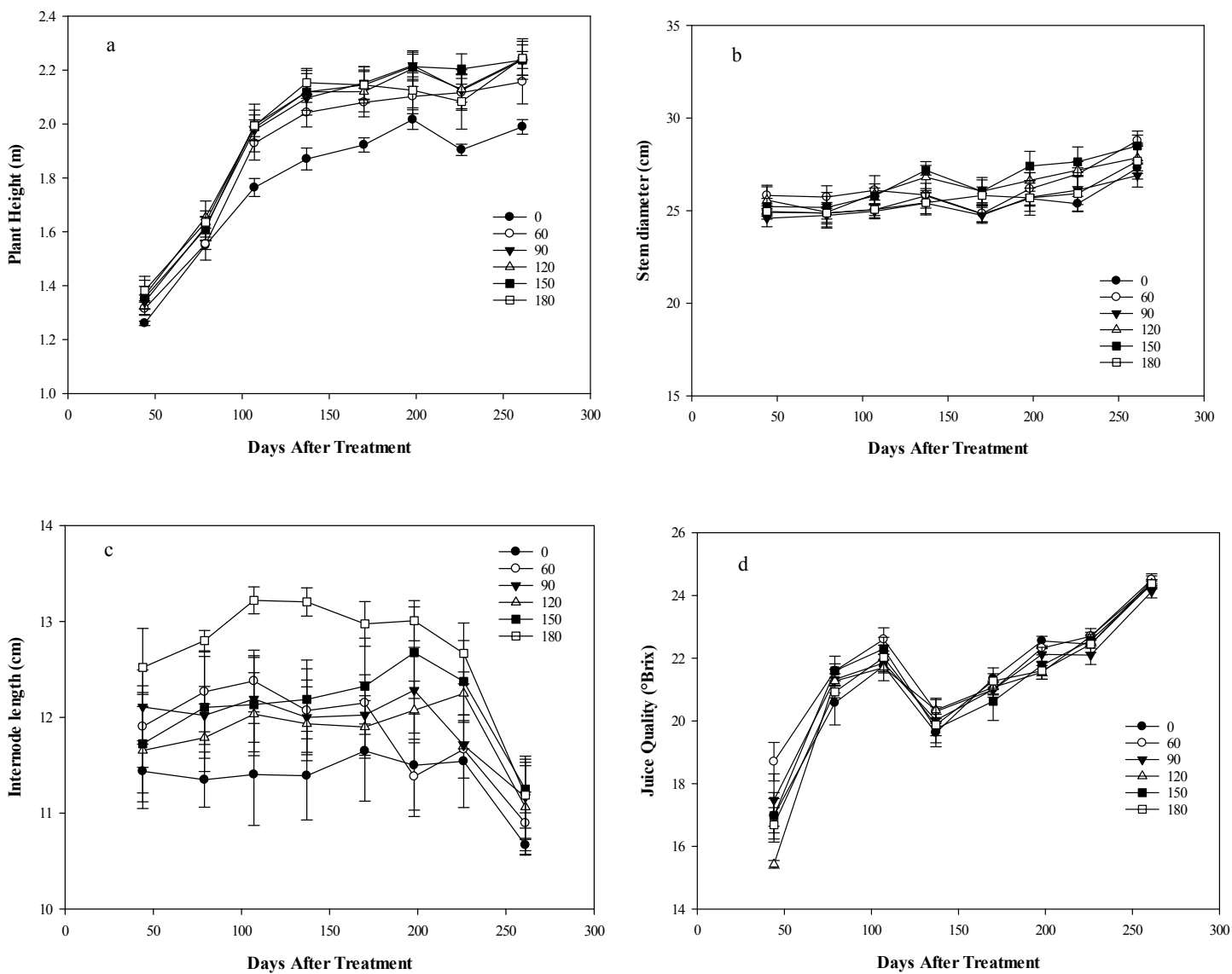

Figure 2. Changes with time in plant height (a), stem diameter (b), internode length (c), and ${ }^{\circ}$ Brix (d) during growth as affected by soil nitrogen content.

\section{Physiological Parameters}

Photosynthesis, growth, and yield are associated with $\mathrm{N}$ availability, especially in sugarcane (LEMAIRE; GASTAL, 2018; TAIZ; ZEIGER, 2006; SHEKINAH; SUNDARA; RAKKIYAPPAN, 2012; DINH et al., 2019); it is a long duration crop and requires a lot of nutrients. This response was observed in this experiment. For physiological parameters, there were highly significant differences in $\mathrm{A}, \mathrm{g}_{\mathrm{s}}, \mathrm{E}$, and SPAD units but non-significant differences regarding $T_{\text {leaf }}$ between both dose treatments and light response (PAR). The interaction doses $\mathrm{x}$ PAR was nonsignificant for all physiological parameters (Table 3), except for $\mathrm{E}$. The coefficient of variation in parameters such as $\mathrm{A}$ and $\mathrm{g}_{\mathrm{s}}$ indicates a high variability. Similar responses for A, gs, E, and SPAD units were previously reported when studying different genotypes and different levels of $\mathrm{N}$ (ZHAO; GLAZ; COMSTOCK, 2014; KUMARA; BANDARA, 2001), but not for the results obtained in other experiments (IZQUIERDO-HERNANDEZ et al., 2016) concerning the effect of $\mathrm{N}$ dose. Overall, the photosynthetic rate varied with the daytime, and reached the highest level at $14 \mathrm{~h}$ (Figure 3a). The photosynthetic rate was higher at $90 \mathrm{~kg} \mathrm{~N} \mathrm{ha}{ }^{-1}$ (Figure $3 b)$ than the other doses of nitrogen $(+18.3 \%$ with respect to $0 \mathrm{~N}$ ). The photosynthetic rate of 120 $\mathrm{kg} \mathrm{N} \mathrm{ha}{ }^{-1}$ was significantly lower than the A values of $0 \mathrm{~N}(-6.1 \%)$, although these values are influenced by the amount of solar radiation received by plants. In general, our results indicate that the application of $\mathrm{N}$ fertilizer significantly affects the A in sugarcane, although this depends on the doses and the time of the day in which the photosynthesis value is taken. Leaf SPAD readings varied with $\mathrm{N}$ doses, compared with $0 \mathrm{~N}$, and reached the highest level at $150 \mathrm{~kg} \mathrm{~N}$ $\mathrm{ha}^{-1}$ (Figure 3c). These results differ from those obtained by Izquierdo-Hernandez et al. (2016) who reported non-significant differences in chlorophyll activity with different doses of $\mathrm{N}$ and therefore suggesting that the content of $\mathrm{N}$ in the soil was satisfactory. Lower $A$ and SPAD readings in $0 \mathrm{~N}$ may be associated with a significant reduction in leaf $\mathrm{N}$ and chlorophyll, probably due to a reduction of two important molecules in sugarcane photosynthesis, namely ribulose 1, 5 bisphosphate carboxylase/oxygenase (rubisco) and phosphoenylpyruvate (PEP) (TAIZ; ZEIGER, 2006). The role of $\mathrm{N}$ is important in chlorophyll formation and carbohydrate metabolism, and in positive interactions with other elements to improve the growth and yield of the sugarcane. In this study, all doses of $\mathrm{N}$ contributed to further increase the crop growth or crop yield (Figures 2 and 5). 
Table 3. Summary of analysis of variance for physiological characteristics in response to soil nitrogen content in ratoon crop.

\begin{tabular}{|c|c|c|c|c|c|c|}
\hline Source & d.f. & $\begin{array}{c}\mathrm{A} \\
\left(\mu \mathrm{mol} \mathrm{CO} \mathrm{CO}^{-2} \mathrm{~s}^{-1}\right)\end{array}$ & $\begin{array}{c}\mathrm{gs} \\
\left(\mathrm{mol} \mathrm{m}_{-2} \mathrm{~s}^{-1}\right)\end{array}$ & $\begin{array}{c}\mathrm{E} \\
\left(\mathrm{mmol} \mathrm{H}_{2} \mathrm{O} \mathrm{m}^{-2} \mathrm{~s}^{-1}\right)\end{array}$ & $\begin{array}{l}\mathrm{T}_{\text {leaf }} \\
\left({ }^{\circ} \mathrm{C}\right)\end{array}$ & $\begin{array}{l}\text { Yield } \\
\left(\text { t.ha }^{-1}\right)\end{array}$ \\
\hline Doses (DN) & 5 & $<0.001$ & $<0.05$ & $<0.01$ & $\mathrm{~ns}$ & $<0.001$ \\
\hline PAR & 4 & $<0.001$ & $<0.001$ & $<0.001$ & ns & \\
\hline DN $x$ PAR & 20 & $\mathrm{~ns}$ & ns & $<0.001$ & ns & \\
\hline $\mathrm{CV}(\%)$ & & 23.8 & 21.6 & 16.7 & 1.5 & 6.7 \\
\hline
\end{tabular}

d.f.: degrees of freedom; PAR: photosynthetically active radiation; A: photosynthetic rate; gs: stomatal conductance; E: transpiration rate; $\mathrm{T}_{\text {leaf: }}$ : leaf temperature.
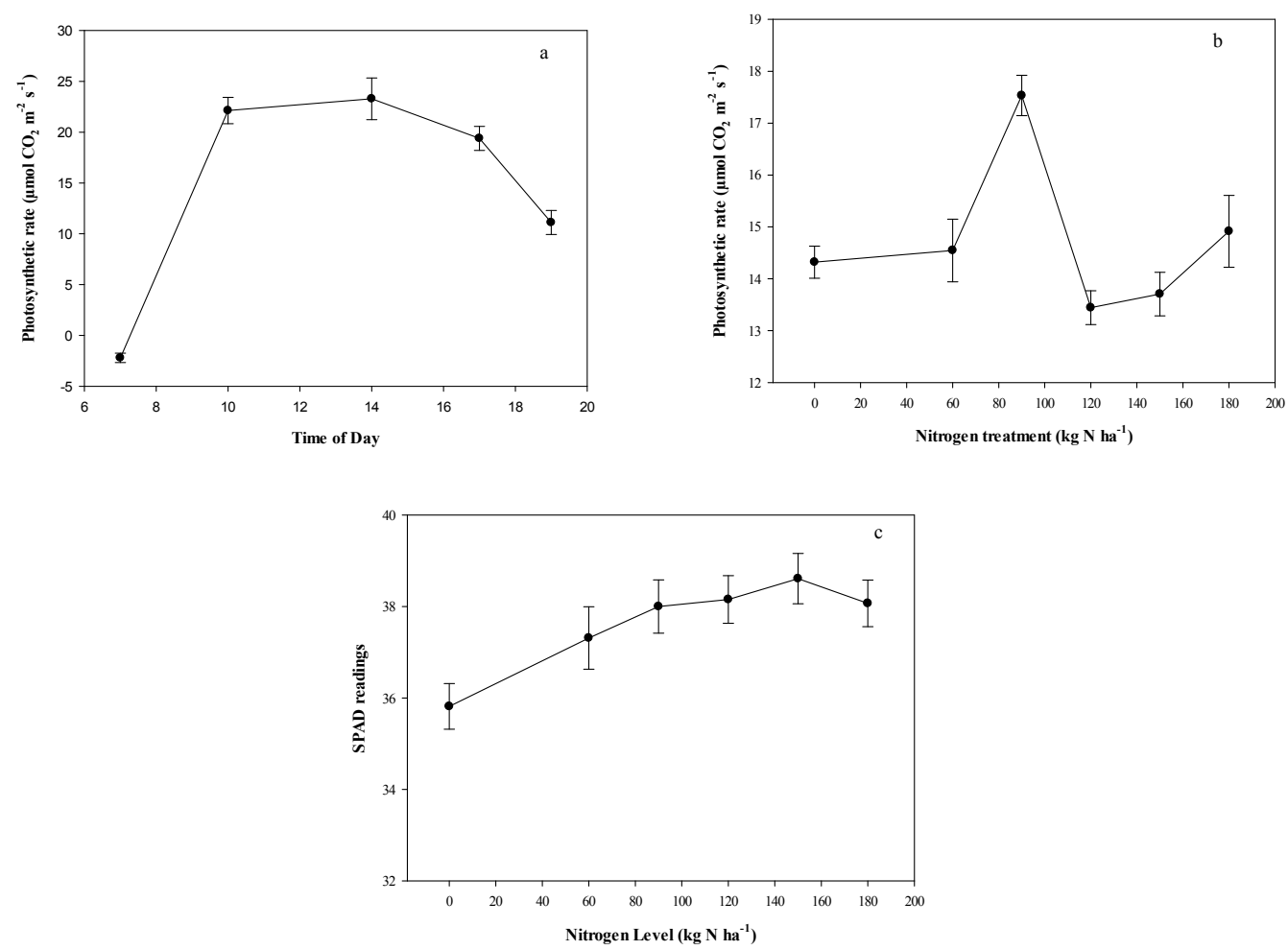

Figure 3. Photosynthetic rate response to PAR (a) and nitrogen level (b), and SPAD readings (c) of six nitrogen doses in ratoon crop.

Figure 4 shows the light response curves obtained for the different $\mathrm{N}$ dose treatments. The maximum A $\left(27.68 \mu \mathrm{mol} \mathrm{CO} \mathrm{CO}^{-2} \mathrm{~s}^{-1}\right)$ levels were attained at $14 \mathrm{~h}\left(\approx 1500 \mu \mathrm{mol} \mathrm{m} \mathrm{m}^{-2} \mathrm{~s}^{-1}\right)$ with $90 \mathrm{~kg} \mathrm{~N}$ $\mathrm{ha}^{-1}$ (Figure 4a). The same response was observed for $E$ and $T_{\text {leaf }}$ (Figure $4 \mathrm{c}, \mathrm{d}$ ). The values of $\mathrm{A}$, obtained in Mex 79-431 grown under rainfed conditions, were similar to those observed in other experiments (ZHAO; GLAZ; COMSTOCK, 2014; IZQUIERDOHERNANDEZ et al., 2016; KUMARA; BANDARA, 2001; RANJITH; MEINZER, 1997) under different levels of $\mathrm{N}$. For stomatal conductance, the response was not consistent for the doses of $\mathrm{N}$ (Figure 4b). Overall, SPAD readings varied significantly with respect to doses of nitrogen during all dates (Figure 4e). SPAD readings reached the highest level with $150 \mathrm{~kg} \mathrm{~N}^{-1}$ at 198 days after treatment. From 44 to 79 DAT, only the $0 \mathrm{~N}$ treatment had significantly lower SPAD readings compared to the other $\mathrm{N}$ treatments. The SPAD readings, after 107 DAT in the treatment of $150 \mathrm{~kg} \mathrm{~N}$ $\mathrm{ha}^{-1}$, had the highest values compared to the other $\mathrm{N}$ treatments until harvest. After 198 DAT, the SPAD readings in all treatments sharply declined until the end of the cycle (261 DAT). This period coincides with the maturity stage, where the leaf area reached its maximum growth and where photosynthetic activity is reduced.

\section{Cane Yield}

Cane yield showed a significant difference with increasing levels of nitrogen application (Table 2 ). The application of $\mathrm{N}$ had a positive effect on growth, development, and physiological processes (Figures 2 and 4). Higher $\mathrm{N}$ levels helped in increasing the cane yield (Figure 5). The increasing cane yield as a function of $\mathrm{N}$ doses was adjusted to 
quadratic model, with maximum points estimated for the rates of $120 \mathrm{~kg} \mathrm{~N} \mathrm{ha}^{-1}$. The highest cane yield was recorded in ratoon crop with a dose between 90 and $120 \mathrm{~kg} \mathrm{~N} \mathrm{ha}{ }^{-1}$. A higher cane yield was harvested due to plant height and internode length. Our results indicate that at $60 \mathrm{~kg} \mathrm{~N} \mathrm{ha}^{-1}$, the highest yield was obtained $\left(96.3 \mathrm{t} \mathrm{ha}^{-1}\right)$, with an increase of $19.8 \mathrm{t} \mathrm{ha}^{-1}$. On the other hand, the treatment of 150 $\mathrm{kg} \mathrm{N} \mathrm{ha}{ }^{-1}$ had an increase of $16.6 \mathrm{t} \mathrm{ha}^{-1}$. The increases in cane yield varied from 7.47 to $19.8 \mathrm{t}$, depending on the doses. Similar results were observed by Srinivas et al. (2003) and Naga Madhuri et al. (2011). Using high doses of $\mathrm{N}$ at 336 and
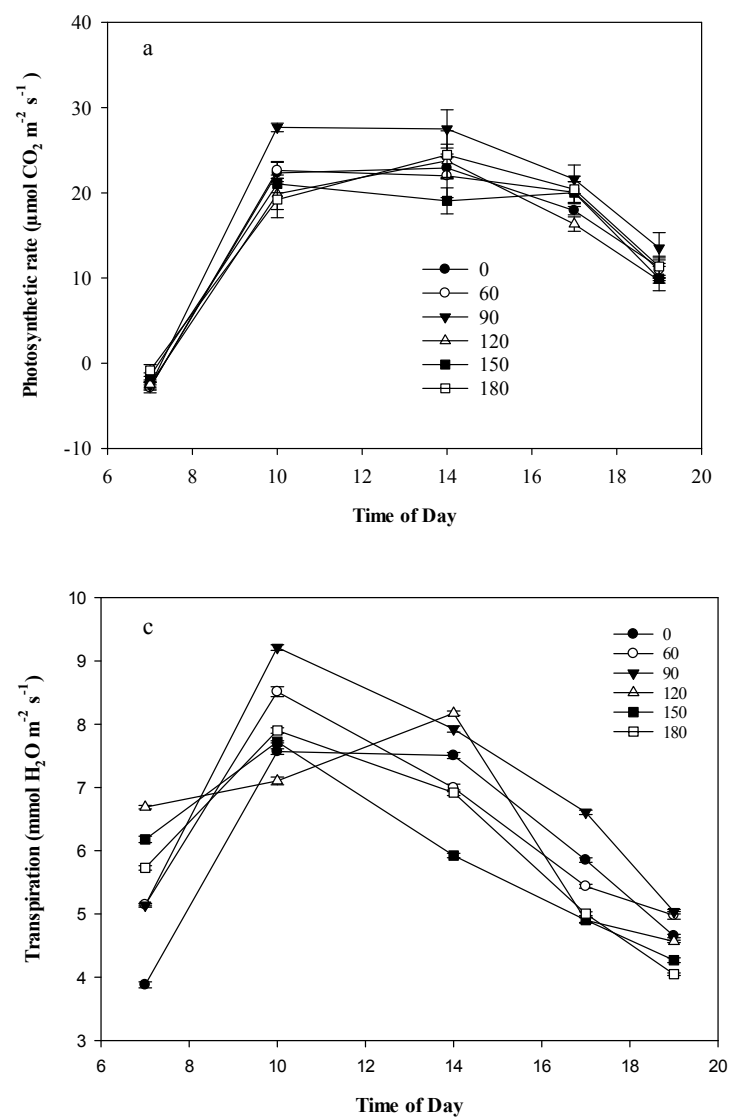

$375 \mathrm{~kg} \mathrm{~N} \mathrm{ha}^{-1}$ and with increases in yields of up to $14.26 \mathrm{t} \mathrm{ha}^{-1}$, depending on the genotype, Shekinah, Sundara and Rakkiyappan (2012) found a positive effect on growth and development processes and the highest yield $\left(118.6 \mathrm{t} \mathrm{ha}^{-1}\right)$ in ratoon crop with application rate of $280 \mathrm{~kg} \mathrm{~N} \mathrm{ha}{ }^{-1}$. However, this applied dose is well above the recommended dose in the region of our study $\left(+160 \mathrm{~kg} \mathrm{~N} \mathrm{ha}^{-1}\right)$. Doses higher than the dose prescribed by sugar mills $\left(120 \mathrm{~kg} \mathrm{~N} \mathrm{ha}^{-1}\right)$ make the cultivation of sugarcane more expensive under stress conditions brought by drought and high temperatures.
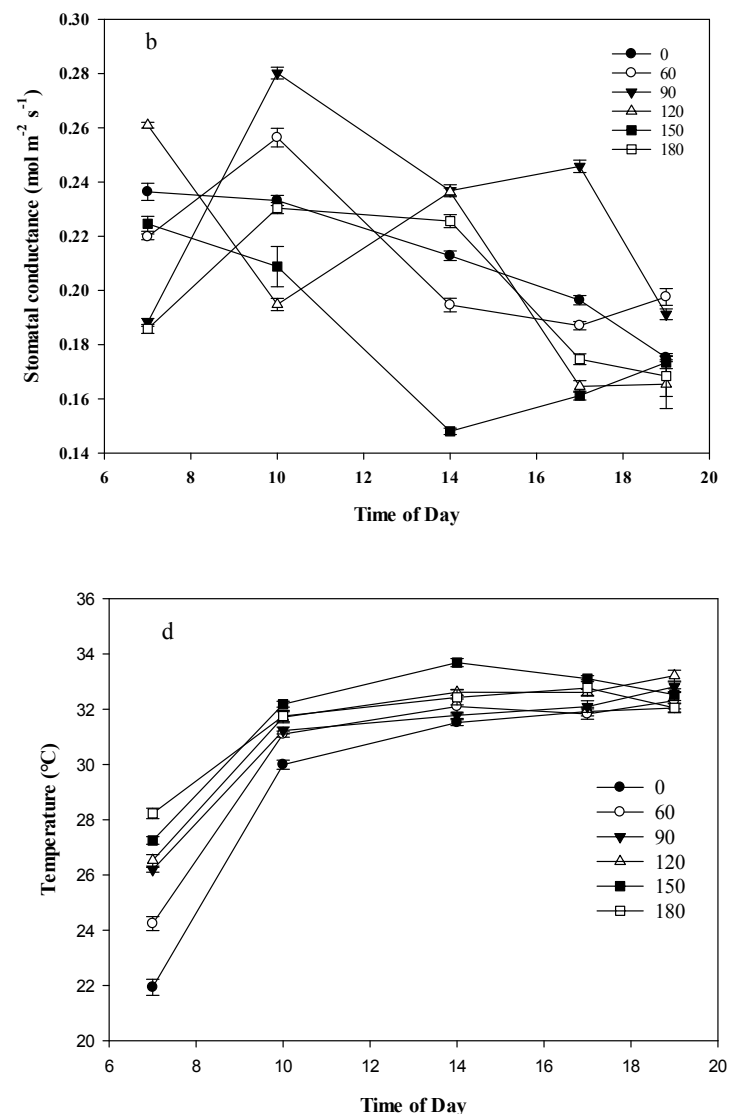

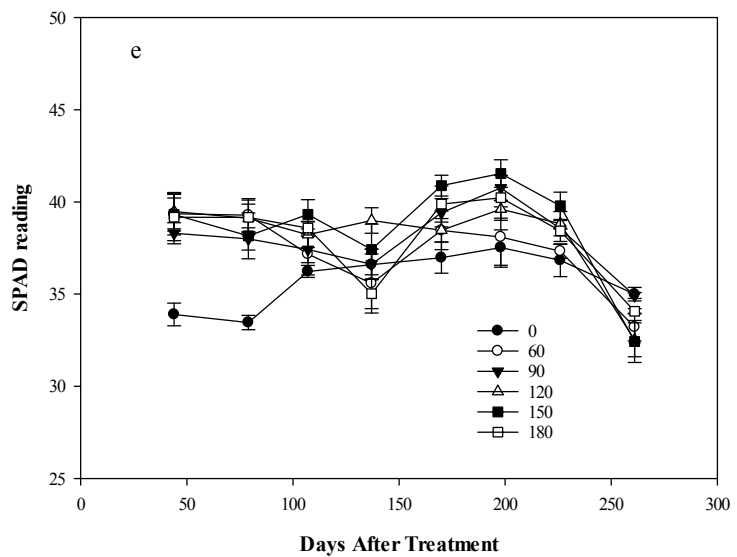

Figure 4. Effect of nitrogen application doses on physiological characteristics in response to PAR (a, b, c and d) and during growth (e) in ratoon crop. 
In general, the yield in ratoon crop with any dose of $\mathrm{N}$ applied in the early stages was significantly higher than the treatment of $0 \mathrm{~N}$ because the higher nutrition level helped in increasing the millable canes and maintaining them (SHEKINAH; SUNDARA; RAKKIYAPPAN, 2012). The genotype Mex 79-431 responded positively to the applied nitrogen doses. Higher nutrition levels at early stages helped in increasing growth and metabolism because $\mathrm{N}$ also contributes in chlorophyll and carbohydrate formation and interacts with phosphorus and potassium to improve sugarcane vigor (SHUKLA, 2007; SHEKINAH; SUNDARA; RAKKIYAPPAN, 2012). The aforementioned coincides with the results obtained in this study, where all $\mathrm{N}$ doses applied contributed to the increase in yield, as a result of a higher growth of the crop, mainly plant height.

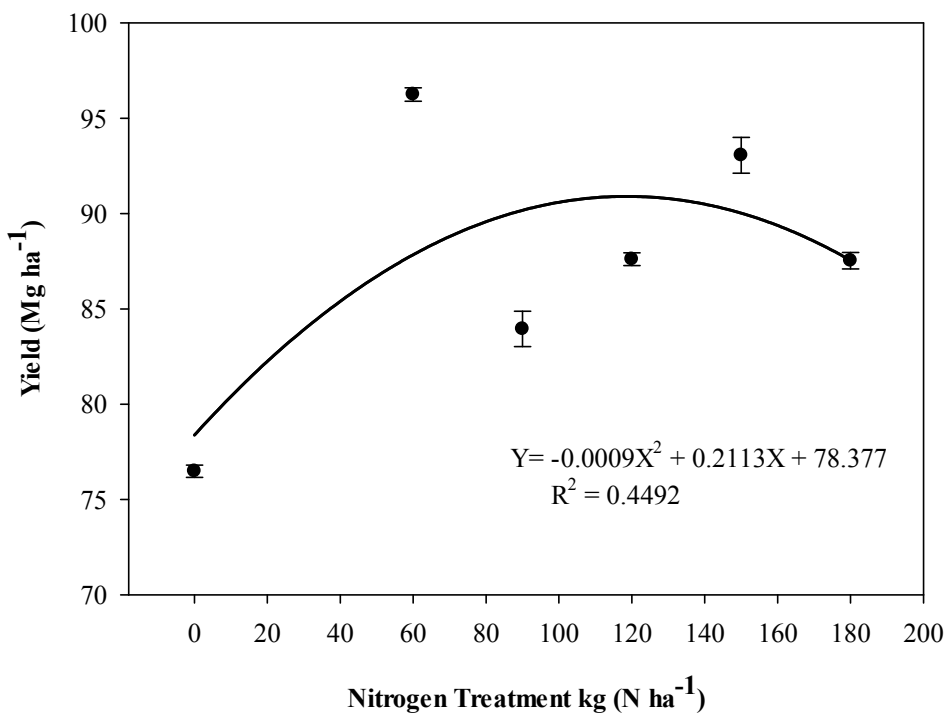

Figure 5. Relationship between nitrogen dose treatment and yield of second ratoon crop under field conditions. Standard errors are indicated by vertical bars.

\section{Juice Quality}

Nitrogen is essential for cane growth and juice quality. The quality of the crop is assessed by the sugar produced per ton of cane. The juice quality characteristic of sugarcane in ratoon crop (Table 1), as indicated by ${ }^{\circ}$ Brix, was significantly $(\infty=0.05)$ influenced by $\mathrm{N}$ levels, especially at the beginning of the study (Figure 2). This response could be due to the early application of $\mathrm{N}$. In fact, throughout the experiment, there was a very similar trend with all $\mathrm{N}$ treatments during growth and development, reaching an average of $21.3^{\circ}$ Brix at harvest. However, at this stage, the differences between $\mathrm{N}$ doses were not significant and although the average value obtained in this study was higher (24.4 ${ }^{\circ}$ Brix $)$, the results coincided with those obtained by Bologna-Campbell, Franco and Vitti (2013), Shekinah, Sundara and Rakkiyappan (2012), and Naga Madhuri et al. (2011). This means that the quality of the juice is an intrinsic characteristic of the genotype, rather than an influence of the $\mathrm{N}$ content in the soil or the tissues of sugarcane.

\section{CONCLUSIONS}

The results of the experiment clearly showed that the application of $\mathrm{N}$ in ratoon crop had a positive effect on agronomic parameters, such as plant height, stem diameter, and internode length, as well as on physiological processes, such as photosynthesis rate, transpiration, stomatal conductance, and SPAD readings. The highest yield recorded in the ratoon crop was with a dose treatment of $120 \mathrm{~kg} \mathrm{~N}^{-1}$. At harvest, the juice quality did not show a significant variation with the treatments imposed. It is important to note that further studies on timing of nitrogen application, application methods, soil types, other doses, and other genotypes would be necessary to bring even more understanding on the subject.

\section{REFERENCES}

BOLOGNA-CAMPBELL, I.; FRANCO, H. C. J.; VITTI, A. C. Impact of nitrogen and sulphur fertilizers on yield and quality of sugarcane plant 
crop. Sugar Tech, 15: 424-428, 2013.

BONNETT, G. D. Developmental stages (Phenology). In: MOORE, P. H.; BOTHA, F. C. (Eds.). Sugarcane: Physiology, Biochemistry, and Functional Biology. Ames, Iowa: John Wiley \& Sons, Inc., 2014. v. 1, cap. 3, p. 35-53.

CASTRO, N. S.; HUERTA, A. J. Response of sugarcane varieties (Saccharum officinarum L.) to NPK fertilization on dry land in southern Tamaulipas. Revista Mexicana de Ciencias Agrícolas, 6: 2225-2232, 2015.

DINH, T. H. et al. Leaf photosynthesis response to change of soil moisture content in sugarcane. Sugar Tech, 21: 949-958, 2019.

EZENWA, I. V. et al. Establishment and management of sugarcane on organic-amended vs. non-amended mineral soils. Journal of American Society of Sugar Cane Technologists, 25: 107-108, 2005.

FIDEICOMISOS INSTITUIDOS EN RELACIÓN CON LA AGRICULTURA - FIRA. 2015. Informe de la Dirección de Investigación y Evaluación Económica y Sectorial. Panorama Agroalimentario - Azúcar 2015. Disponível em: $<$ https://www.gob.mx/cms/uploads/attachment/ file/61947/

Panorama_Agroalimentario_Az_car_2015.pdf >. Acesso em: 16 aug. 2018.

GALLAIS, A.; COQUE, M.; BERTIN, P. Response to selection of a maize population for adaptation to high or low nitrogen fertilization. Maydica, 53: 2128,2008 .

GILBERT, R. A. et al. Sugarcane response to mill mud, fertilizer, and soybean nutrient sources on a sandy soil. Agronomy Journal, 100: 845-854, 2008.

HARI， K.; SRINIVASAN， T. R. Response of sugarcane varieties to application of nitrogen fixing bacteria under different nitrogen levels. Sugar Tech, 7: 28-31, 2005.

ISA, D. W.; HOFMAN, G.; VAN CLEEMPUT, O. Uptake and balance of fertilizer nitrogen applied to sugarcane. Field Crops Research, 95: 348-354, 2006.

IZQUIERDO-HERNÁNDEZ, J. et al. Nutritional and physiological response of sugarcane varieties to nitrogen fertilization in a haplic cambisol. Sugar Tech, 18: 493-499, 2016.

JAGTAP, S. M.; JADHAVI, M. B.; KULKARM, R. $\mathrm{V}$. Effect of levels of NPK on yield and quality of sugarcane (cv. Co. 7257). Indian Sugar, 56: 35-40, 2006.

KUMARA, A. D. S.; BANDARA, D. C. Influence of nitrogen application and varietal differences on selected physiological parameters of sugarcane. Tropical Agricultural Research, 13: 220-230, 2001.

LEMAIRE, G.; GASTAL, F. Crop responses to nitrogen. In: MEYERS, R. A. (Ed.) Encyclopedia of Sustainability Science and Technology. New York, NY: Springer, 2018. v. 1, p. 159-184.

NAGA MADHURI, K. V. et al. Response of promising midlate maturing sugarcane varieties to different doses of nitrogen fertilizer. Journal of Sugarcane Research, 1: 49-54, 2011.

NAGA MADHURI, K. V.; HEMANTH, K. M.; SARALA, N. V. Influence of higher doses of nitrogen on yield and quality of early maturing sugarcane varieties. Sugar Tech, 13: 96-98, 2011.

RANJITH, S. A.; MEINZER, F. C. Physiological correlates of variation in nitrogen-use efficiency in two contrasting sugarcane cultivars. Crop Science, 37: 818-825, 1997.

REYNOLDS, M. P. et al. Application of physiology in wheat breeding. In: REYNOLDS, M. P.; ORTIZMONASTERIO, J. I.; MCNAB, A. (Eds.) Application of physiology in wheat breeding. Mexico, DF: CIMMYT, 2001. v. 1, p. 2-10.

ROZEFF, N.; WIEDENFELD, R. P. Fertilizing sugarcane in South Texas. In: ROZEFF, N.; AMADOR, J. M.; IRVINE, J. E. (Eds.). South Texas sugarcane production handbook. Santa Rosa, Tx, USA: Texas A \& M University, Research \& Extension Center at Weslaco and Rio Grande Valley Sugar Growers, Inc., 1998. p. 10-14.

SALGADO-GARCÍA, S. et al. Basis for generating a sustainable fertilization program at a sugar mill in Tabasco, Mexico. Interciencia, 30: 395-403+443, 2005.

SAS INSTITUTE INC. SAS/STAT User's guide. Version 9.2. SAS Institute, Inc. Cary, North Carolina, USA. 2010. 1689 p.

SHEKINAH, D. E.; SUNDARA, B.; RAKKIYAPPAN, P. Relative significance of $\mathrm{N}$ nutrition on yield, quality and ethanol in sugarcane (Saccharum species hybrid) plant: ratoon system. Sugar Tech, 14: 134-137, 2012.

SHUKLA, S. K. Productivity and economics of high -sugar genotypes of sugarcane (Saccharum 
officinarum hybrid complex) in plant-ratoon system under various planting seasons and fertility levels. Indian Journal of Agronomy, 52: 164-167, 2007.

SERVICIO DE INFORMACIÓN Y ESTADÍSTICA AGROALIMENTARIA Y PESQUERA - SIAPSAGARPA. 2018. Sistema producto. Disponível em: <http://www.siap.gob.mx>. Acesso em: 16 aug. 2018.

SRINIVAS, D. et al. Influence of levels of nitrogen on the yield and quality of early maturing sugarcane varieties. Cooperative Sugar, 34: 479-482, 2003.

TAIZ, L.; ZEIGER, E. Plant Physiology. 4th ed, Sinauer Associates Inc. Sunderland, MA., USA. pp. 145-170, 2006.

THORBURN, P. J.; MEIER, E. A.; PROBERT, M. E. Modelling nitrogen dynamics in sugarcane systems: Recent advances and applications. Field Crops Research, 92: 337-351, 2005.

WIEDENFELD, R. P. Effects of irrigation and N fertilizer application on sugarcane yield and quality. Field Crops Research, 43: 101-108, 1995.

WIEDENFELD, B.; ENCISO, J. Sugarcane responses to irrigation and nitrogen in semiarid South Texas. Agronomy Journal, 100: 665-671, 2008 .

ZHAO, D.; GLAZ, B.; COMSTOCK, J. C. Sugarcane responses to water-deficit stress during early growth on organic and sand soils. American Journal of Agricultural and Biological Sciences, 5: 403-414. 2010.

ZHAO, D.; GLAZ, B.; COMSTOCK, J. C. Physiological and growth responses of sugarcane genotypes to nitrogen rate on a sand soil. Journal of Agronomy and Crop Science, 200: 290-301, 2014. 